JEL: Q15, Q24, Q50

Anatolii Kucher ${ }^{1,2,3}$, Lesia Kucher ${ }^{4}$, Inna Sysoieva ${ }^{5}$, Borys Pohrishchuk ${ }^{5}$

${ }^{1} V . N$. Karazin Kharkiv National University
${ }^{2}$ NSC «Institute for Soil Science and Agrochemistry Research
named after O. N. Sokolovsky»
${ }^{3}$ University of Agribusiness and Rural Development
${ }^{4}$ State Biotechnological University
${ }^{5}$ Vinnytsia Education and Research Institute of Economics
of West Ukrainian National University
${ }_{1,2,4,5}$ Ukraine
${ }^{3}$ Bulgaria

\title{
ECONOMICS OF SOIL EROSION: CASE STUDY OF UKRAINE
}

Purpose. The main objective of this paper is (i) to determinate the economic loss due to crop productivity loss caused by soil erosion in Ukraine, and (ii) to present the results of the econometric modeling of soil erosion impact on the efficiency crop production at the regional and district level.

Methodology / approach. This study uses the following methods: expert assessments and monographic (for the assessment of economic losses due to crop productivity loss from spreading soil erosion); graphical (for building three-dimensional graphs); econometric modeling (to develop a mathematical model of the dependence of the gross crop production and income from sales per 100 hectares from the share of eroded arable land in its total area and production costs in crop industry per 100 hectares); abstract-and-logical (for generalization of the research results). To solve the assigned tasks, linear and quadratic econometric models (production functions) were developed using a dataset (i) from 168 observations (on the example of Ukrainian regions for 2010-2016) and (ii) from 189 observations (on the example of districts of Kharkiv region for 2010 2016). This study was conducted in order to test the hypothesis that the increase in the area of eroded arable land has a negative effect on the gross output of crop production.

Results. Our expert assessment of economic losses due to crop productivity loss from spread of soil erosion on agricultural land in Ukraine is $224 \mathrm{mln}$ USD. The obtained results confirm the hypothesis about the negative relationship between gross crop output and the level of land erosion. The obtained data confirm that an increase in the area of eroded arable land by $1 \%$ leads to a decrease in the gross output of crop production by $0.20 \%$ per 100 hectares of agricultural land in total, and in the third group of the studied subjects (the share of eroded arable land in their total area is more than $50 \%$ ) - by $0.61 \%$, respectively.

Originality / scientific novelty. For the first time, linear and nonlinear (quadratic) econometric models were developed, which made it possible to carry out quantitative assessment of the impact of the soil erosion and the financial support (production costs in crop industry) per hectare on the formation of the financial results (gross crop output and income) of business entities in Ukrainian agriculture. The provision on the economics of soil erosion was further developed in terms of expert assessment of losses from this type of degradation and confirmation of the effect of the economic law of diminishing returns, which should be taken into account when developing measures for sustainable land management.

Practical value / implications. The main results of the study can be used for the development, substantiation and implementation of soil protection measures for the sustainable use of 


\section{Agricultural and Resource Economics: International Scientific E-Journal}

http://are-journal.com

agricultural land and/or to informed decision-making at different levels of management concerning restoration of eroded land.

Key words: agricultural productivity, economic losses, soil erosion, production costs, impact of soil erosion on the production of crop products.

Introduction and review of literature. The economics of soil erosion has received relatively little attention until recent years. Although a number of studies have undertaken to quantify the costs of soil erosion, studies that address the economics of soil erosion are still scarce [1]. Soil erosion negatively affects crop yields. However, the issue of how significant is this impact remains debatable. For example, Bakker et al. [2] show that future reductions in productivity through soil erosion in Europe as a whole are relatively small and do not pose a substantial threat to crop production within the coming century. However, within Europe there is considerable variability, and for the southern countries the threat of erosion-induced productivity declines is stronger [2]. At the same time, according to Panagos et al. [3], soil erosion by water is one of the major threats to soils in the European Union (EU), with a negative impact on ecosystem services, crop production and carbon stocks. The mean soil loss rate in the EU is estimated to $2.46 \mathrm{t} /$ hectare annually, resulting in a total soil loss of $970 \mathrm{Mt}$ annually. About $12.7 \%$ of European arable lands have soil loss $>5 \mathrm{t} /$ hectare annually requiring protection [3]. Although some studies have addressed the issue of reduced crop productivity due to soil erosion, few have focused on the economic loss in terms of agriculture [4]. In one such study, an economic assessment of soil erosion in the EU was carried out. According to Panagos et al. [4] the $12 \mathrm{mln}$ hectares of agricultural areas in the EU that suffer from severe erosion are estimated to lose around $0.43 \%$ of their crop productivity annually. The annual cost of this loss in agricultural productivity is estimated at around $1.2 \mathrm{bln}$ Euro. The highest economic losses are typical for Italy, whereas the agricultural sector in most Northern and Central European countries is only marginally affected by soil erosion losses [4]. As far as we know, in Ukraine there are no such assessments according to this methodology.

Nearly all of Europe is affected by soil erosion. To mitigate the impacts of soil erosion, the European Union's Common Agricultural Policy has introduced conservation measures which reduce soil loss by water erosion by $20 \%$ in arable lands. A major policy response is required to reverse the impacts of erosion in degraded areas, particularly in light of the current climate change [5].

Various aspects of soil erosion are covered in the works of such scientists as: Achasov et al. [6], Bernoux et al. [7], Borrelli et al. [8; 9], Liu et al. [10], Martín Fernández et al. [11], Menshov et al. [12], Panagos et al. [3-5], Pham et al. [13], Tessema et al. [14], Shao [15], Timchenko et al. [16], Vávra et al. [17], and others [18-21]. Water erosion is a threat for numerous arable lands in Ukraine (Fig. 1). There is strong evidence that soil erosion in Ukraine is accelerating, leading to major natural damage in other ways too, such as siltation of rivers, harbors, and dam reservoirs (which feed hydroelectric power stations). But the problem is more acute 


\section{Agricultural and Resource Economics: International Scientific E-Journal http://are-journal.com}

in some areas than others: in the south-east of the country, for example, soil has been eroded to the extent of desertification [22].

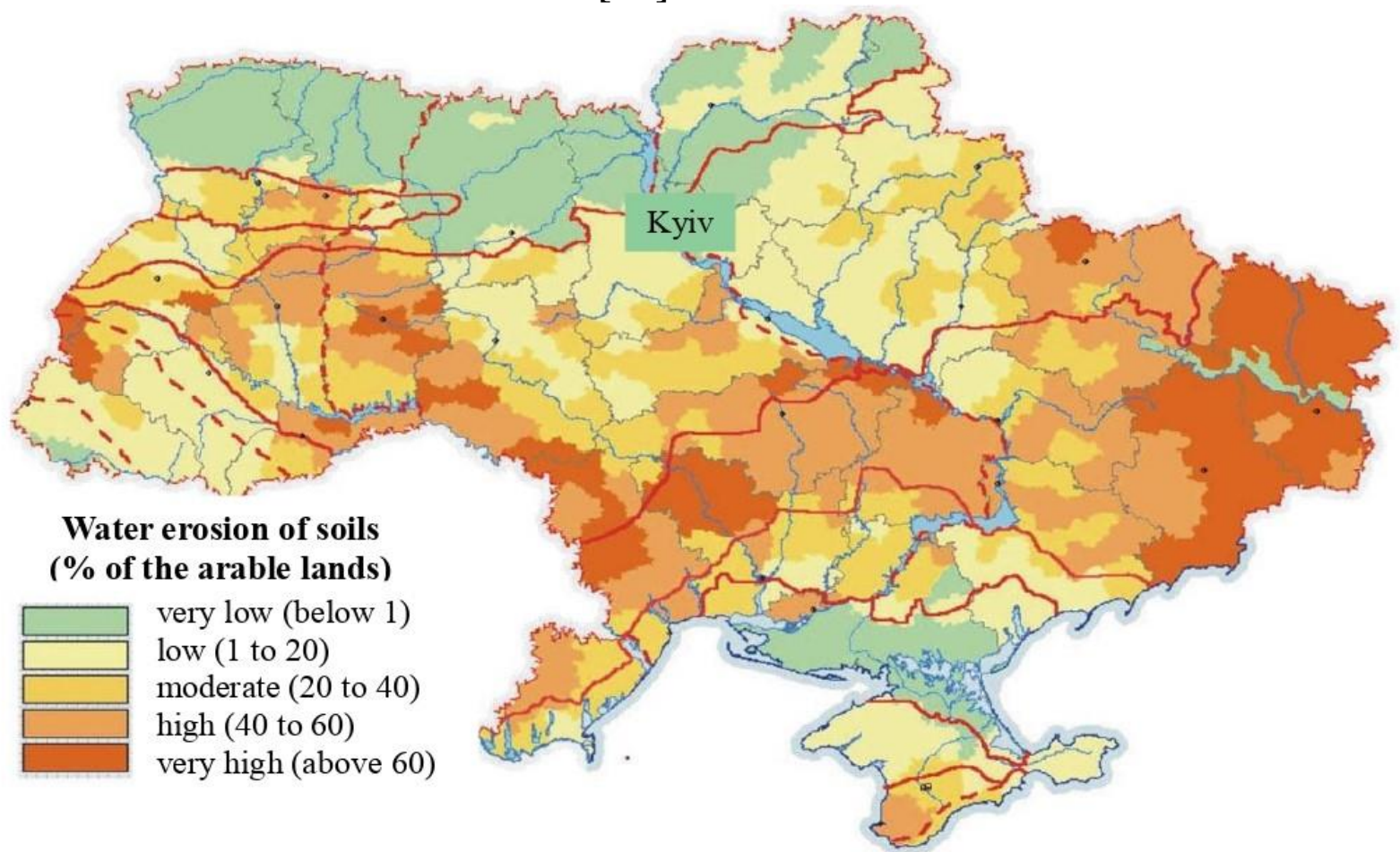

\section{Fig. 1. The share of eroded arable land (by water erosion) in its total area} in Ukraine

Source: [7].

According to the search and analysis of the documents in Scopus (search object - "economics of soil erosion"; search scale - all fields), 132 documents were found. Based on the review of articles on economics of soil erosion indexed by Scopus during 1982 and 2021 (Fig. 2), we identified (i) a growth trend in the number of publications in the world (leaders - USA, Canada, Australia, Germany and India), and (ii) research gaps in Ukrainian literature (not a single document has been published by Ukrainian scientists), that have not yet been addressed.
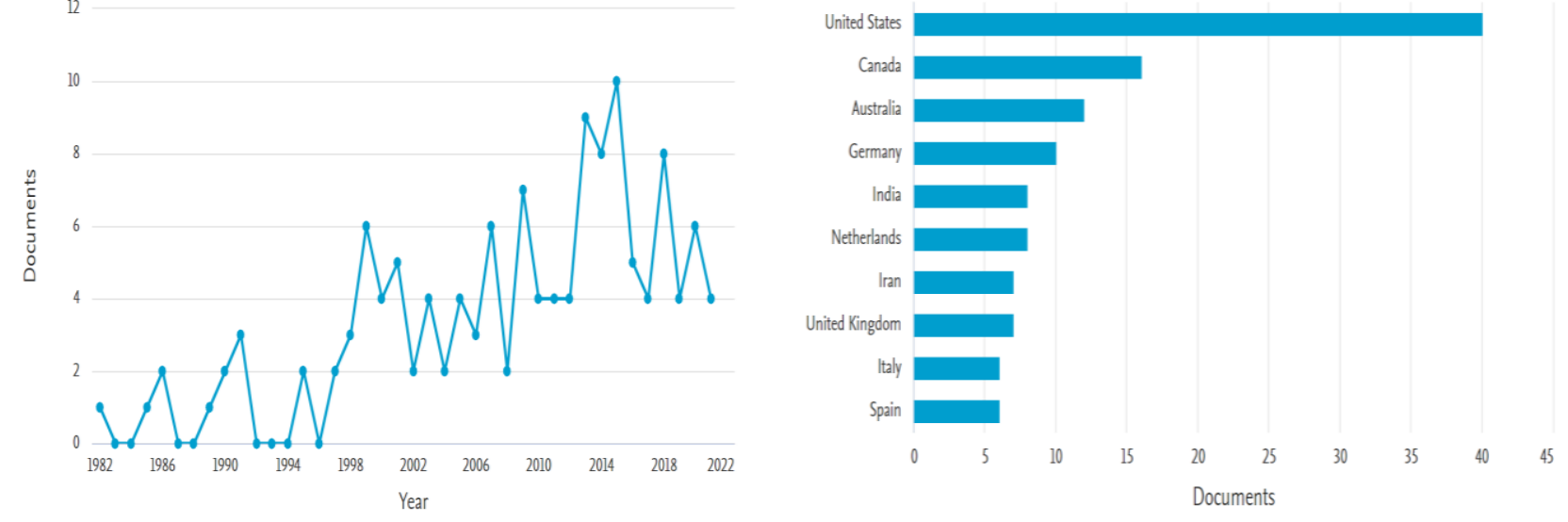

Fig. 2. Number of documents on "economics of soil erosion" published in journals indexed by Scopus in dynamics and in the TOP-10 countries Source: built on the basis of Scopus database. 
Analysis of the distribution of documents by type shows that the largest share (70.5\%) is made up of articles (Fig. 3).

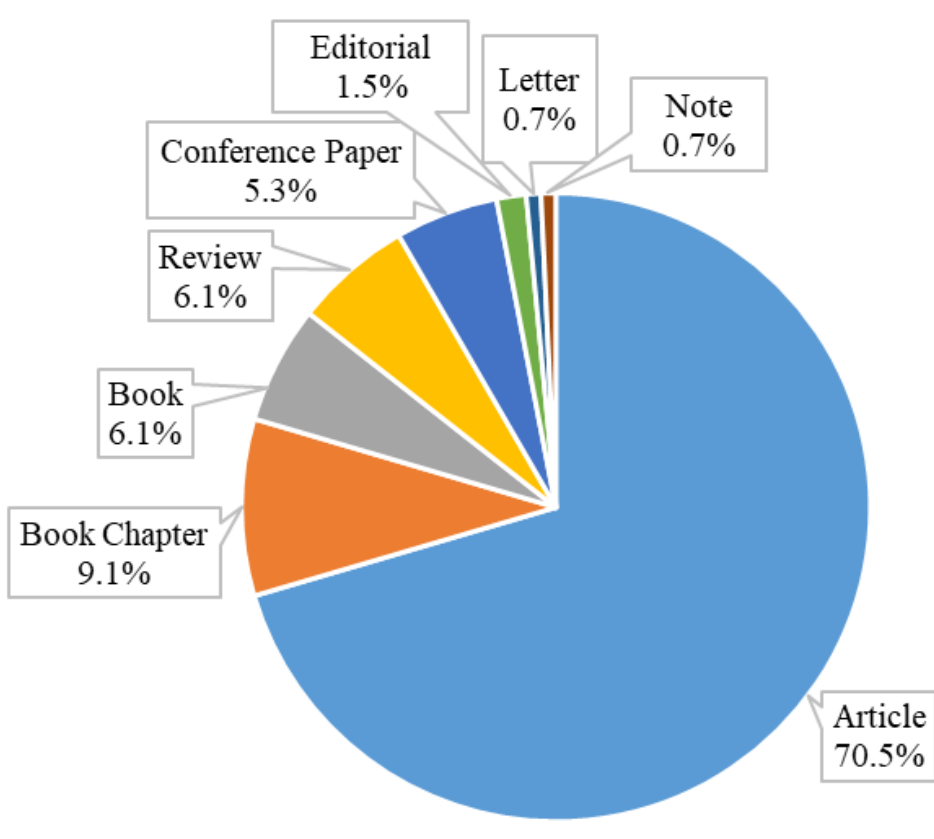

\section{Fig. 3. Distribution of documents on "economics of soil erosion" published in journals indexed by Scopus by type, 1982-2021}

Source: built on the basis of Scopus database.

Analysis of the distribution of documents by subject area (Fig. 4) shows that the largest number of publications fell on environmental science $(28.2 \%)$, agricultural and biological sciences $(26.1 \%)$ and economics, econometrics and finance $(16.2 \%)$.

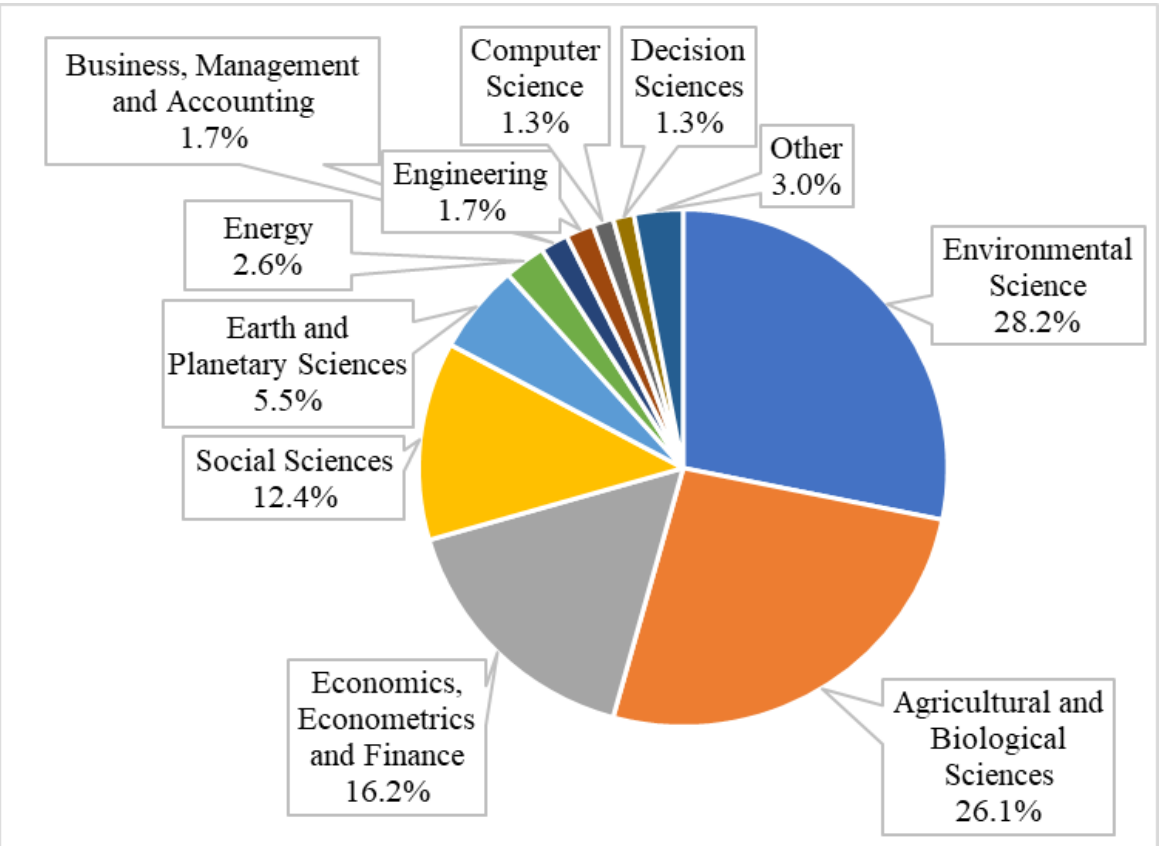

Fig. 4. Distribution of documents on "economics of soil erosion" published in journals indexed by Scopus by subject area, 1982-2021

Source: built on the basis of Scopus database. 


\section{Agricultural and Resource Economics: International Scientific E-Journal}

http://are-journal.com

The interdisciplinary nature of the economics of soil erosion indicates the need to intensify scientific cooperation between soil scientists, agronomists and economists to conduct comprehensive research.

In terms of the number of publications on the economics of soil erosion, the most influential organizations in the world are the University of Wisconsin-Madison and Wageningen University \& Research. Analysis of the distribution of documents in the context of the main sources of publication indicates that the largest number of studies was published in the following journals: Ecological Economics (4 documents), Land Degradation and Development (4 documents), American Journal of Agricultural Economics (3 documents), Journal of Food Agriculture and Environment (3 documents), World Development (3 documents).

However, up to present the problem of economic assessment of impact of soil erosion on the production of crop products in Ukraine is not covered sufficiently, thus determining the topicality of this research issue. Therefore, the proposed article is a logical continuation of the scientific research of the authors on this topic [19-20;23], in particular those that were presented by one of the co-authors at the Global Symposium on Soil Erosion (GSER19) at The Food and Agriculture Organization (FAO) [24]. The methodological basis of this study is the fundamental provisions of modern ecological economics and economics of land degradation.

The purpose of the article. The main objective of this paper is (i) to determinate the economic loss due to crop productivity loss caused by soil erosion in Ukraine, and (ii) to present the results of the econometric modeling of soil erosion impact on the efficiency crop production at the regional and district level.

Results and discussion. Soil erosion is the major challenge that threatens the comparative advantage and competitiveness of Ukrainian crop production systems. "It is estimated that more than $500 \mathrm{mln}$ t of soil are eroded annually from arable land in Ukraine resulting in loss of soil fertility across $32.5 \mathrm{mln}$ hectares and equivalent to around 5 bln USD in nutrient equivalent. This represents a significant loss of the main agricultural productive asset of the country: its soils. The value of eroded soil each year is around one-third of the agricultural gross domestic product (GDP). This means that for each dollar of added agricultural value, one-third is lost through erosion; or ten tonnes of soil are eroded for each t of grain produced" [7].

Erodibility of agricultural lands has already arrived at $40 \%$. There are $24 \mathrm{mln} \mathrm{t}$ of humus, $1 \mathrm{mln} t$ of nitrogen, 700 thousand $\mathrm{t}$ of phosphorus, $10 \mathrm{mln} \mathrm{t}$ of potassium are lost yearly. There are from 8 to 30 t/hectare average washing-off from tillage yearly and differ by regions. The complete damage of erosion is more, then $10 \mathrm{bln}$ USD per year, it is approximately equals to the National budget of Ukraine [18].

According to our expert assessment (Fig. 5), the total economic loss (loss of income from sales) due to crop productivity loss caused by soil erosion in Ukraine is about 5.7 bln UAH (or 0.224 bln USD). The total amount of lost profit due to crop productivity loss caused by soil erosion is about $1136 \mathrm{mln}$ UAH (or $44.5 \mathrm{mln}$ USD).

As a result of the correlation analysis, a statistically significant weak inverse relationship $(\mathrm{r}=-0.227)$ was revealed between the share of eroded arable land in its 
total area and the gross crop production in agricultural enterprises of Ukrainian regions per 100 hectares of agricultural land. However, the volume of gross crop production per unit of land area had a high direct correlation $(r=0.773)$ with the intensity of production. At the same time, agricultural enterprises did not always invest more in those regions where more eroded arable land is concentrated, since a moderate backward correlation link was identified between them $(r=-0.350)$.

Economic losses (loss of income from sales) due:

soil degradation including soils erosion

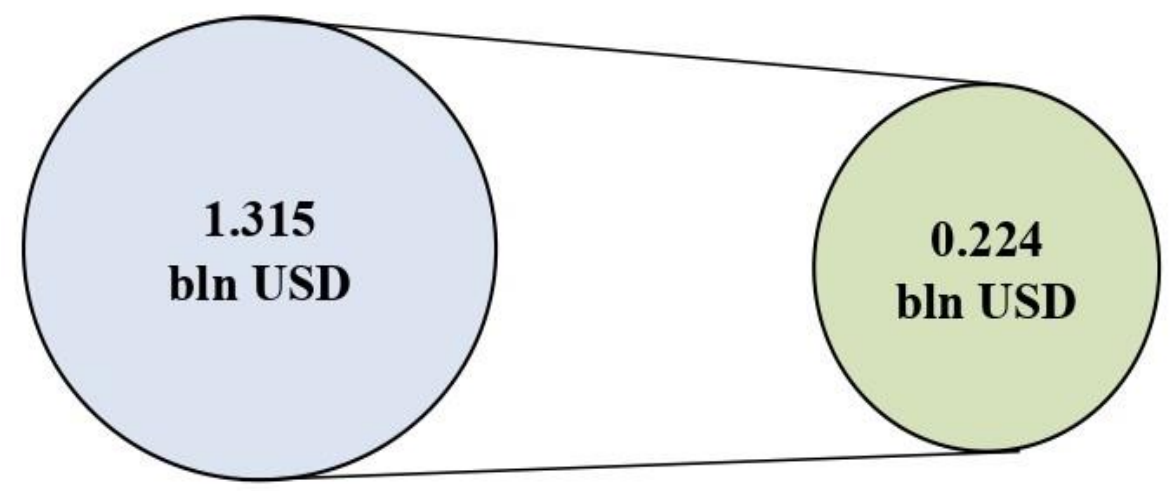

\section{Fig. 5. Expert assessment of economic losses (loss of income from sales) due to crop productivity loss from spreading soil degradation, in particular, their erosion in Ukraine}

Source: authors' research.

The parameters of the constructed linear two-factor econometric model (Fig. 6) indicate that an increase in the share of eroded arable land in its total area by 1 percentage point (pp) caused a decrease in volume of gross output of crop production by $69.6 \mathrm{USD} / 100$ hectares of agricultural land, while with the increase in production costs by 1 thousand USD/100 hectares of arable land, the volume of these products increased by $600.8 \mathrm{USD} / 100$ hectares of agricultural land. The quadratic model indicates a nonlinear (polynomial) dependence of the volume of gross output of crop production from the intensity of its production, which is the result of the economic law of diminishing returns, while the higher the level of erosion of arable land, the more it is necessary to invest money to obtain the same amount of products.

The next step of our study was to assess the impact of land erosion on the analyzed economic indicators by grouping the regions of Ukraine by the share of eroded arable land in its total area, resulting in the formation of three groups of objects:

(i) regions with a relatively small amount of eroded arable land (up to $30.0 \%$, 70 observations), which are characterized by the following average values of indicators: the share of eroded arable land $-17.8 \%$; wheat yield $-3.82 \mathrm{t} / \mathrm{hectare}$; production costs in crop industry per 100 hectares of arable land - 59.7 thousand USD; gross output of crop production per 100 hectares of agricultural land 49.9 thousand USD; 


\section{$\mathrm{y}=15.2125+0.6008 \mathrm{x}_{2}-0.0696 \mathrm{x}_{1}$}

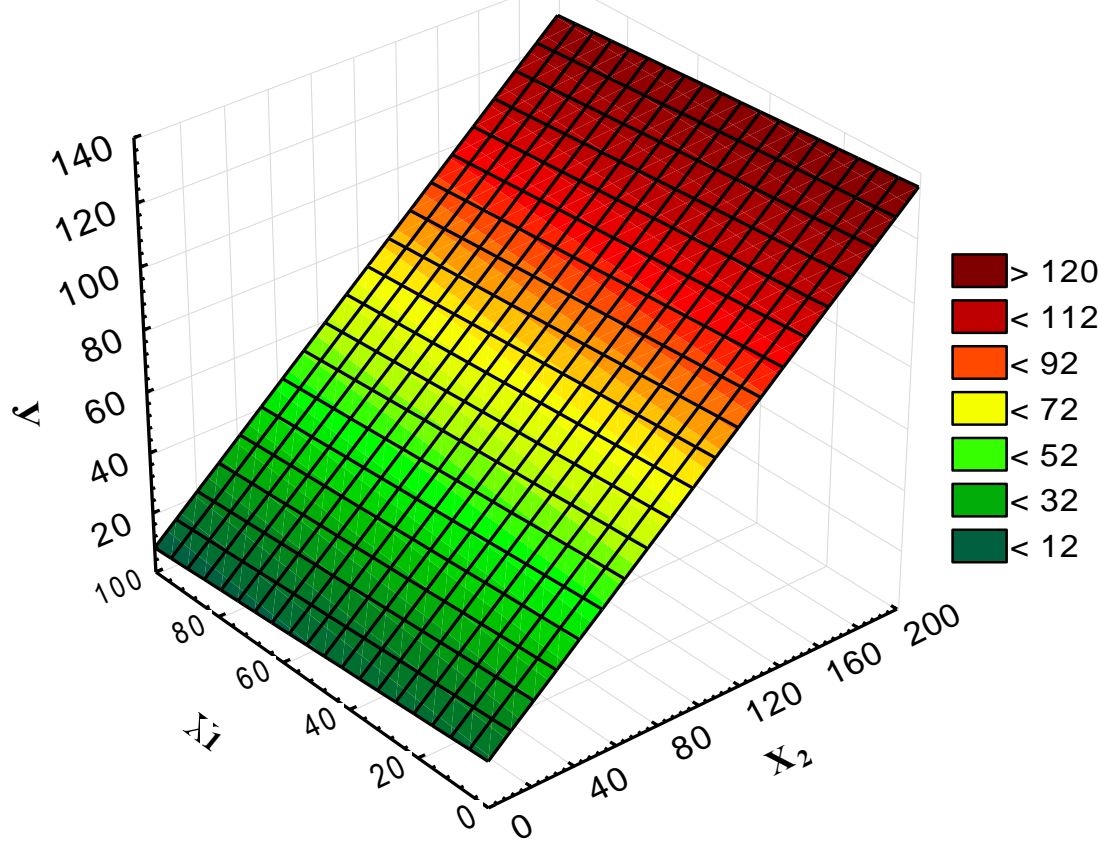

a)

$$
\mathrm{y}=-13.1393+1.3616 \mathrm{x}_{2}+0.0798 \mathrm{x}_{1}-0.0048 \mathrm{x}_{2}^{2}-0.0002 \mathrm{x}_{1} \mathrm{x}_{2}-0.0007 \mathrm{x}_{1}^{2}
$$

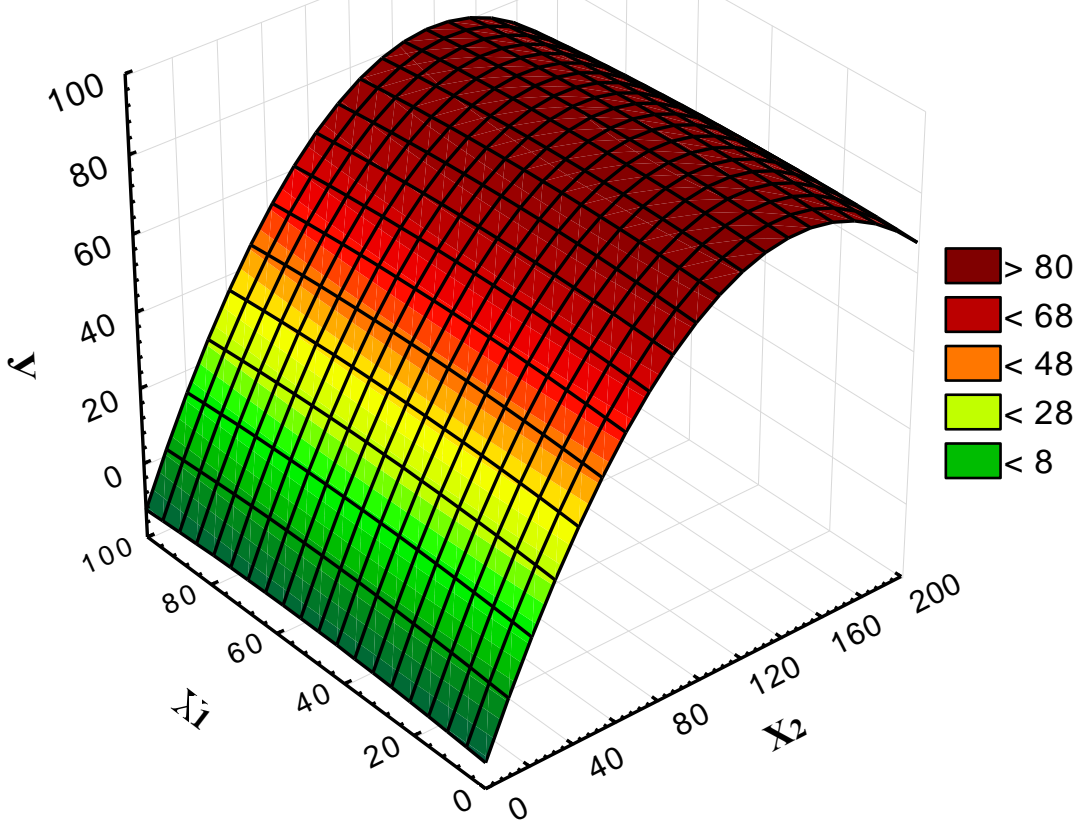

b)

Fig. 6. Linear (a) and quadratic (b) models of the dependence of gross crop production per 100 hectares of agricultural land $(Y$, thousand USD) from the share of eroded arable land in its total area $\left(X_{1}, \%\right)$ and production costs in crop industry per 100 hectares of arable land ( $X_{2}$, thousand USD) using the example of agricultural enterprises of Ukrainian regions, 2010-2016

Source: built by the authors on the basis of their own research according to the form number 50-s.g. and data of the State Service of Ukraine for Geodesy, Cartography \& Cadastre. 
(ii) regions with an average amount of eroded arable land (30.1-50.0\%, 56 observations), they are characterized by the following average values of indicators: the share of eroded arable land $-38.4 \%$; wheat yield $-3.73 \mathrm{t} / \mathrm{hectare}$; production costs in crop industry per 100 hectares of arable land - 55.5 thousand USD; gross output of crop production per 100 hectares of agricultural land 45.8 thousand USD;

(iii) regions with a relatively large amount of eroded arable land (more than $50.0 \%, 42$ observations), they are characterized by the following average values of indicators: the share of eroded arable land $-62.2 \%$; wheat yield $-3.10 \mathrm{t} / \mathrm{hectare}$; production costs in crop industry per 100 hectares of arable land - 39.3 thousand USD; gross output of crop production per 100 hectares of agricultural land 34.4 thousand USD.

Thus, with an increase in the share of eroded arable land, wheat yields and gross output of crop production per 100 hectares of agricultural land decreased; compared to the first group in the third group they were on average 18.8 and $34.2 \%$ less, respectively.

The developed econometric models are statistically significant, reliable and adequate, as evidenced by the values of the Fisher's F-criterion and Student's t-test (Table 1).

Table 1

Parameters of econometric models of dependence of the gross crop production per 100 hectares of agricultural land from the share of eroded arable land in its total area and production costs in crop industry per 100 hectares of arable land using the example of agricultural enterprises of the regions of Ukraine, 2010-2016

\begin{tabular}{|c|c|c|}
\hline \multirow{2}{*}{ Statistical characteristics } & \multicolumn{2}{|c|}{ Indicators and their meanings $(n=168)$} \\
\hline & Linear model & Quadratic model \\
\hline $\begin{array}{l}\text { Coefficient of multiple } \\
\text { correlation }(R)\end{array}$ & $R=0.720$ (high correlation) & $R=0.788$ (high correlation) \\
\hline $\begin{array}{l}\text { Coefficient of multiple } \\
\text { determination }\left(R^{2}\right)\end{array}$ & $\begin{array}{c}R^{2}=0.519 \text { (statistically significant } \\
\text { because significance } F<0.05)\end{array}$ & $\begin{array}{c}R^{2}=0.620 \text { (statistically significant } \\
\text { because significance } F<0.05 \text { ) }\end{array}$ \\
\hline Fisher's F-criterion & $\begin{array}{c}F_{f a c t}=88.9 ; F_{t a b l}=2.16-\text { at } 95 \% \\
\text { probability level; } F_{f a c t}>F_{t a b l}\end{array}$ & $\begin{array}{c}F_{f a c t}=52.9 ; F_{t a b l}=5.16-\text { at } 95 \% \\
\text { probability level; } ; F_{f a c t}>F_{t a b l}\end{array}$ \\
\hline Student's t-criterion & $\begin{array}{c}t_{f a c t}=19.2 ; t_{t a b l}=1.98-\text { at } 95 \% \\
\text { probability level; } t_{\text {fact }}>t_{\text {tabl }}\end{array}$ & $\begin{array}{c}t_{f a c t}=26.6 ; t_{t a b l}=1.98-\text { at } 95 \% \\
\text { probability level; } t_{f a c t}>t_{t a b l}\end{array}$ \\
\hline $\begin{array}{l}\text { Standard error of } \\
\text { estimation }\end{array}$ & 13.21 & 11.85 \\
\hline
\end{tabular}

Source: authors' calculations.

The determination coefficient shows that the variation in the volume of gross output of crop production was explained by $51.9-62.0 \%$ of the variability by the included factors, which closely correlated with the resultant indicator.

At the same time, the quantitative value of one of the regressors $\left(\mathrm{X}_{1}\right)$ in both models turned out to be statistically insignificant (Table 2) for the selected $95 \%$ probability level, that is, the probability of error when using them exceeds $5 \%$. 
Consequently, these models can be applied to make individual decisions, however, for forecasting, it is necessary to improve their reliability.

Table 2

Results of estimation of parameters of econometric models of dependence of the gross crop production per 100 hectares of agricultural land from the share of eroded arable land in its total area and production costs in crop industry per 100 hectares of arable land using the example of agricultural enterprises of Ukrainian regions, 2010-2016

\begin{tabular}{|c|c|c|c|c|c|c|c|c|c|c|}
\hline \multirow{2}{*}{$\begin{array}{c}\text { Vari- } \\
\text { ables }\end{array}$} & $\begin{array}{c}\text { Regre- } \\
\text { ssors, } \\
\text { coef. }\end{array}$ & $\begin{array}{c}\text { Standard } \\
\text { error }\end{array}$ & $\begin{array}{c}\mathrm{t}- \\
\text { statistics }\end{array}$ & $\begin{array}{c}\text { P- } \\
\text { value }\end{array}$ & $\begin{array}{c}\beta- \\
\text { coef- } \\
\text { ficient }\end{array}$ & $\begin{array}{c}\text { Regre- } \\
\text { ssors, } \\
\text { coef. }\end{array}$ & $\begin{array}{c}\text { Standard } \\
\text { error }\end{array}$ & $\begin{array}{c}\mathrm{t}- \\
\text { statistics }\end{array}$ & $\begin{array}{c}\text { P- } \\
\text { value }\end{array}$ & $\begin{array}{c}\beta- \\
\text { coef- } \\
\text { ficient }\end{array}$ \\
\hline \multicolumn{8}{|c|}{ Linear model } \\
\hline$x_{2}$ & 15.2125 & 3.7283 & 4.0802 & 0.0001 & & -13.139 & 8.6199 & -1.5243 & 0.1294 & \\
\hline$x_{1}$ & -0.6008 & 0.0486 & 12.3511 & 0.0000 & 0.6953 & 1.3616 & 0.1765 & 7.7131 & 0.0000 & 1.5757 \\
\hline$x_{2}{ }^{2}$ & - & - & - & - & - & -0.0048 & 0.0008 & -6.3618 & 0.0000 & -0.9132 \\
\hline$x_{1} x_{2}$ & - & - & - & - & - & -0.0002 & 0.0031 & -0.0635 & 0.9494 & -0.0107 \\
\hline$x_{1}{ }^{2}$ & - & - & - & - & - & -0.0007 & 0.0016 & -0.4644 & 0.6430 & -0.0765 \\
\hline
\end{tabular}

Note. Statistically significant indicators at the level of probability of $95 \%$ are in italics.

Source: authors' calculations.

Based on the constructed linear single-factor econometric model, it was established that an increase in the share of eroded arable land in its total area by $1 \mathrm{pp}$ caused a decrease in volume of gross output of crop production by an average of $250.8 \mathrm{USD} / 100$ hectares of agricultural land. However, as a result of one-factor regression analysis in the context of the above three groups, it was found that only in the third group the land degradation factor had a statistically significant negative impact on the resultant indicator, that is, with an increase in the share of eroded arable land by $1 \mathrm{pp}$ in areas where it exceeds $50 \%$ of arable land, the volume of gross output of crop production decreased by an average of $337.4 \mathrm{USD} / 100$ hectares of agricultural land.

The coefficient of elasticity for the single-factor model showed that the increase in eroded arable land by $1 \%$ leads to a decrease in gross crop production by $0.20 \%$ per 100 hectares of agricultural land in aggregate, and in the third group of subjects by $0.61 \%$, respectively. Consequently, the volume of gross crop production in agricultural enterprises of these areas could be large in the absence of soil erosion.

Similar patterns were revealed on the example of agricultural enterprises of the districts of the Kharkiv region (Fig. 7).

The parameters of the linear two-factor econometric model indicate that an increase in the share of eroded arable land in its total area by $1 \mathrm{pp}$ caused a decrease in income from the sale of crop production by $2.23 \mathrm{USD} /$ hectare of arable land, while with an increase in production cost by $1 \mathrm{USD} /$ hectare of arable land, the income increased by $0.96 \mathrm{USD} / \mathrm{hectare}$ of arable land. The obtained mathematical models are statistically significant. 


\section{$\mathrm{y}=208.9384+0.9566 \mathrm{x}_{2}-2.2289 \mathrm{x}_{1}$}

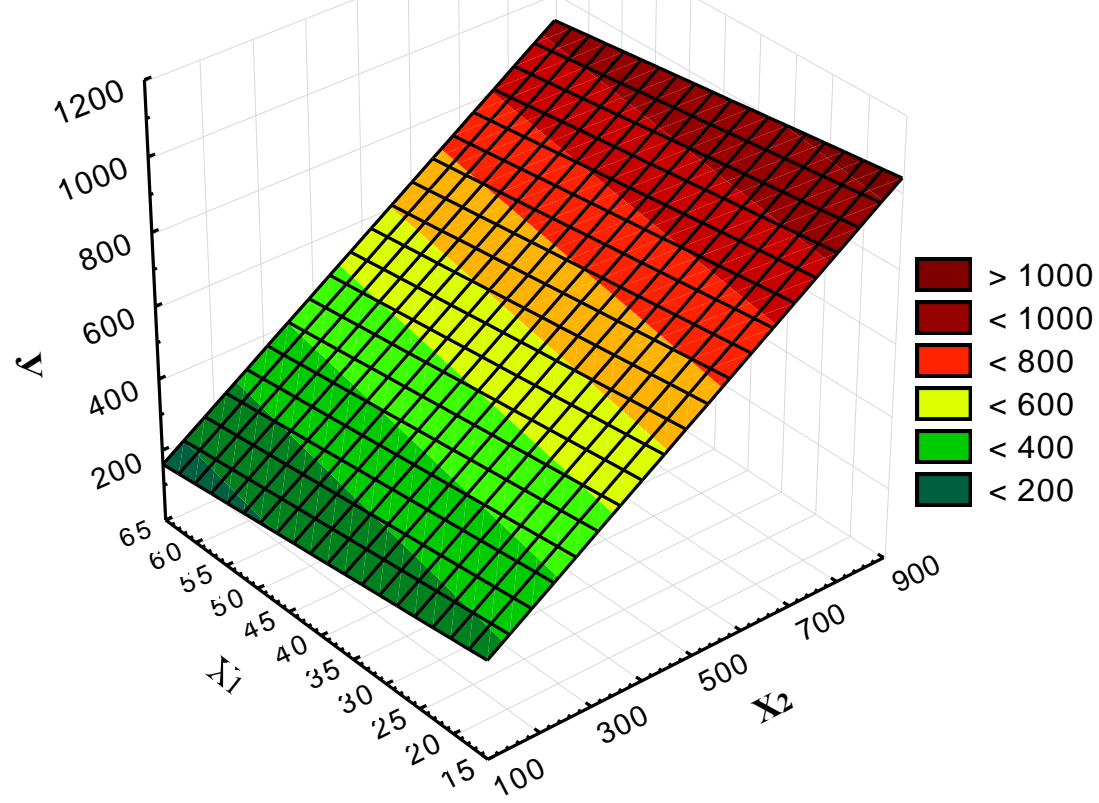

$\mathrm{y}=-98.5823+2.5213 \mathrm{x}_{2}-5.0844 \mathrm{x}_{1}-0.0013 \mathrm{x}_{2}^{2}-0.0073 \mathrm{x}_{1} \mathrm{x}_{2}-0.0780 \mathrm{x}_{1}^{2}$

a)

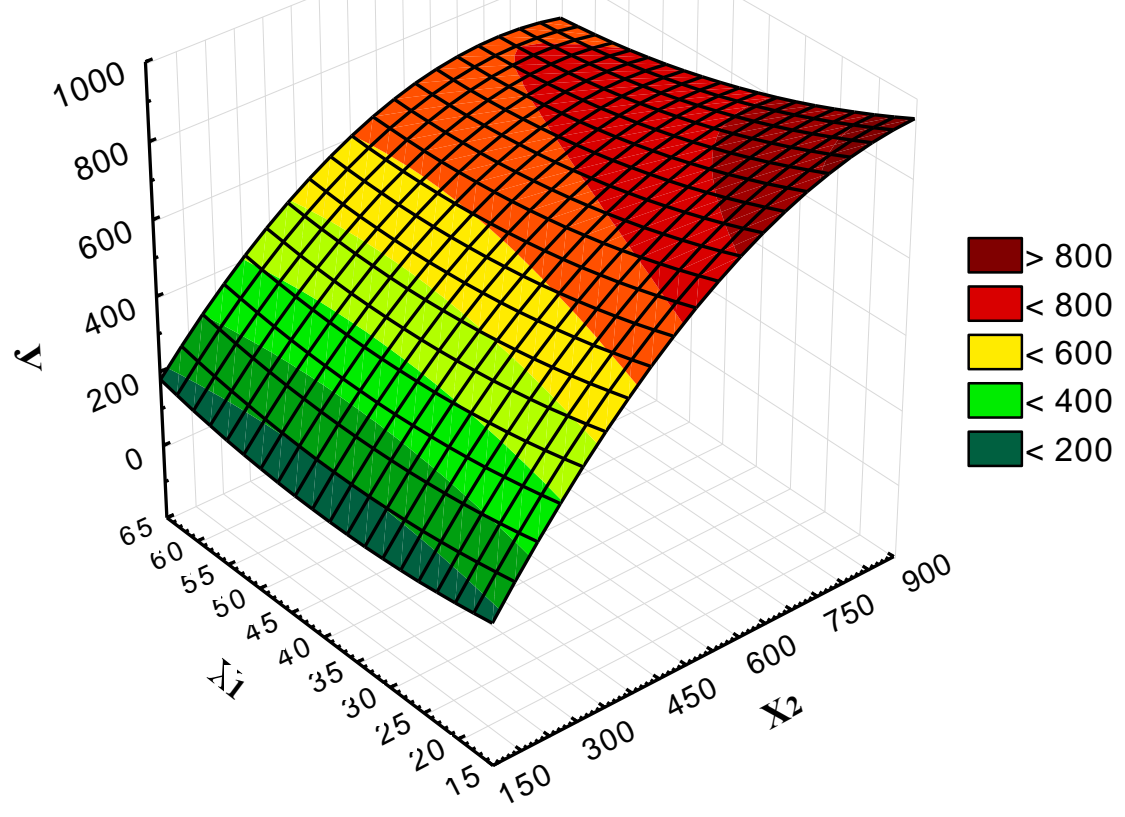

b)

Fig. 7. Linear (a) and quadratic (b) models of the dependence of income from sales of crop production per 1 hectare of arable land $(Y$, USD) from the share of eroded arable land $\left(X_{1}, \%\right)$ and production costs in crop industry per 1 hectare

of arable land $\left(\mathrm{X}_{2}\right.$, USD) using the example of agricultural enterprises of districts of Kharkiv region, 2010-2016

Source: built by the authors on the basis of their own research according to the form number 50-s.g. and data of the State Service of Ukraine for Geodesy, Cartography \& Cadastre. 
In this way both developed econometric models with a probability of $95 \%$ can be considered statistically significant, adequate, high-quality and reliable (Table 3). Thus, the factors included in the model explain more than $51 \%$ of the variation in the resultant indicator; the multiple correlation coefficients indicate a high tightness of the relationship between the selected variables.

Table 3

Parameters of econometric models of dependence of the income from sales of crop production per 1 hectare of arable land from the share of eroded arable land and production costs in crop industry per 1 hectare of arable land using the example of agricultural enterprises of districts of Kharkiv region, 2010-2016

\begin{tabular}{|l|c|c|}
\hline \multicolumn{1}{|c|}{$\begin{array}{c}\text { Statistical } \\
\text { characteristics }\end{array}$} & \multicolumn{2}{|c|}{ Indicators and their meanings $(n=189)$} \\
\cline { 2 - 3 } $\begin{array}{l}\text { Coefficient of } \\
\text { multiple } \\
\text { correlation }(R)\end{array}$ & $R=0.716$ (high correlation) & $R=0.735$ (high correlation) \\
\hline $\begin{array}{l}\text { Coefficient of } \\
\text { multiple } \\
\text { determination }\left(R^{2}\right)\end{array}$ & $\begin{array}{c}R^{2}=0.513 \text { (statistically significant } \\
\text { because significance } F<0.05)\end{array}$ & $\begin{array}{c}R^{2}=0.540 \text { (statistically significant } \\
\text { because significance } F<0.05 \text { ) }\end{array}$ \\
\hline Fisher's F-criterion & $\begin{array}{c}F_{\text {fact }}=98.0 ; F_{\text {tabl }}=2.18-\text { at } 95 \% \\
\text { probability level; } F_{\text {fact }}>F_{\text {tabl }}\end{array}$ & $\begin{array}{c}F_{\text {fact }}=42.93 ; F_{\text {tabl }}=5.18-\text { at } 95 \% \\
\text { probability level; } ; F_{\text {fact }}>F_{\text {tabl }}\end{array}$ \\
\hline $\begin{array}{l}\text { Student's t- } \\
\text { criterion }\end{array}$ & $\begin{array}{c}t_{\text {fact }}=20.1 ; t_{\text {tabl }}=1.97-\text { at } 95 \% \\
\text { probability level; } t_{\text {fact }}>t_{\text {tabl }}\end{array}$ & $\begin{array}{c}t_{\text {fact }}=21.8 ; t_{\text {tabl }}=1.97-\text { at } 95 \% \\
\text { probability level; } ; t_{\text {fact }}>t_{\text {tabl }}\end{array}$ \\
\hline $\begin{array}{l}\text { Standard error of } \\
\text { estimation }\end{array}$ & \multicolumn{1}{c}{112.2} & 109.9 \\
\hline
\end{tabular}

Source: authors' calculations.

The obtained results confirmed the hypothesis put forward and proved the presence of an inverse relationship between the profitability of land use (by the income per 1 hectare) and the degree of their erodibility. Analysis of the standard error, t-test and P-value (Table 4) indicates the statistical significance of all regression coefficients in the linear model; however, in the quadratic model, the influence of the land erosion factor was statistically unreliable at $95 \%$ probability, which can be explained by the linear dependencies between the studied indicators. Therefore, it is the linear econometric model suitable for making managerial decisions and/or forecasts regarding the impact of land erosion on the competitiveness of agricultural enterprises, and the quadratic model can be used to make individual decisions, but not for the forecasts.

The results of a study of the economic assessment of impact of soil erosion on the production of crop products in Ukraine can be used for the development, substantiation and implementation of soil protection measures for the sustainable use of land in the agricultural sector. Practical application of the research results will contribute to informed decision-making at different levels of management.

Based on this study it can be noted that the large scale adoption of climate smart agriculture such as conservation agriculture, combined with effective soil erosion technologies, can potentially have significant benefits for Ukraine. For example, conservation agriculture on $17 \mathrm{mln}$ hectares of land could help generate income of 
4.4 bln USD - equivalent to $34 \%$ of agricultural GDP [22]. At the same time, we note that, according to Chinese scientists, great attention should be paid to the adverse impact of excessive agricultural inputs on soil erosion control. The identification of the socioeconomic driving forces of regional soil erosion could help adjust the development strategy on soil erosion control [25].

Table 4

Results of estimation of parameters of econometric models of dependence of the income from sales of crop production per 1 hectare of arable land from the share of eroded arable land and production costs in crop industry per 1 hectare of arable land using the example of agricultural enterprises of districts of

Kharkiv region, 2010-2016

\begin{tabular}{|l|c|c|c|c|c|c|c|c|c|c|}
\hline \multirow{2}{*}{$\begin{array}{l}\text { Vari- } \\
\text { ables }\end{array}$} & $\begin{array}{c}\text { Regre- } \\
\text { ssors, } \\
\text { coef. }\end{array}$ & $\begin{array}{c}\text { Standard } \\
\text { error }\end{array}$ & $\begin{array}{c}\mathrm{t}- \\
\text { statistics }\end{array}$ & P-value & $\begin{array}{c}\beta \text { - coef- } \\
\text { ficient }\end{array}$ & $\begin{array}{c}\text { Regre- } \\
\text { ssors, } \\
\text { coef. }\end{array}$ & $\begin{array}{c}\text { Standard } \\
\text { error }\end{array}$ & $\begin{array}{c}\mathrm{t}- \\
\text { statistics }\end{array}$ & P-value & $\begin{array}{c}\beta-\text { coef- } \\
\text { ficient }\end{array}$ \\
\hline$y$ & 208.938 & 55.551 & 3.761 & 0.000 & & -98.582 & 253.781 & -0.388 & 0.698 & \\
\hline$x_{1}$ & -2.229 & 0.951 & -2.343 & 0.020 & -0.121 & -5.084 & 7.680 & -0.662 & 0.509 & -0.276 \\
\hline$x_{2}$ & 0.957 & 0.072 & 13.323 & 0.000 & 0.689 & 2.521 & 0.592 & 4.256 & 0.000 & 1.815 \\
\hline$x_{1} x_{2}$ & - & - & - & - & - & -0.007 & 0.008 & -0.878 & 0.381 & -0.269 \\
\hline$x_{1}{ }^{2}$ & - & - & - & - & - & 0.078 & 0.073 & 1.076 & 0.283 & 0.350 \\
\hline$x_{2}{ }^{2}$ & & & & & & -0.001 & 0.000 & -2.998 & 0.003 & -0.919 \\
\hline
\end{tabular}

Note. Statistically significant indicators at the level of probability of $95 \%$ are in italics.

Source: authors' calculations.

One of the promising directions may be the use of the obtained results to improve the stakeholder engagement necessary to support land use changes to improve resilience against erosion. In the modern world overcoming the problems of soil erosion and the transition to the sustainable use of land in agricultural production is impossible without the broad involvement of all interested and stakeholding parties in solving these problems. Dialogue with stakeholders is a key element of effective management at individual farm and state levels. Currently in Ukraine, there is considerable scope and need for significant improvements in this area as only a small number of enterprises involved in the agricultural sector have developed stakeholder engagement tools [20]. In this context, it should be noted that our conclusions coincide with the results of research by European scientists. For example, in the Czech Republic over $75 \%$ of all stakeholders see soil erosion as a big problem; moreover, irresponsible farmers are seen as the most important cause by all stakeholders [20]. At the same time, it should be emphasized that in the Czech Republic, in contrast to Ukraine, despite the lack of efforts at the governmental and legislative levels, local stakeholders support pro-environmental measures to protect soil from erosion.

Conclusions. This paper describes the scale of soil erosion in Ukraine and the economic losses caused by this problem. Our expert assessment of economic losses (loss of income from sales) due to crop productivity loss from spreading soil erosion in Ukraine is $224 \mathrm{mln}$ USD. For the first time, the economic assessment of impact of soil erosion on the production of crop products in Ukraine was conducted. The 
obtained results favor the hypothesis of a negative relationship between gross crop output and the level of land erosion. The findings confirm that the increase in the area of eroded arable land by $1 \%$ leads to a decrease in the gross output of crop production by $0.20 \%$ per 100 hectares of agricultural land in aggregate, and in the third group of subjects (the share of eroded arable land in their total area is more than $50 \%$ ) - by $0.61 \%$, respectively.

The obtained results confirm the hypothesis that the increase in the area of eroded arable land has a negative effect on the financial results (gross output of crop production and income from its sale). For example, in the Kharkiv region the increase in the share of eroded arable land in its total area by $1 \mathrm{pp}$ caused a decrease in income from the sale of crop production by $2.23 \mathrm{USD} /$ hectare of arable land, while with an increase in expenses by $1 \mathrm{USD} / \mathrm{hectare}$ of arable land, the income increased by $0.96 \mathrm{USD} / \mathrm{hectare}$ of arable land. The obtained mathematical models are statistically significant. The quadratic models indicate a nonlinear (polynomial) dependence of the volume of financial results from the financial support for production, which is the result of the economic law of diminishing returns, while the higher the level of erosion of arable land, the more it is necessary to invest money to obtain the same amount of products. Agricultural enterprises do not always invest more in those regions where more eroded arable land is concentrated, since a moderate backward correlation link was identified between them $(r=-0.350)$.

The main results of the study can be used for the development, substantiation and implementation of measures for restoration of eroded land and sustainable soil management. In the future, the following areas of research may be promising: development and implementation of a mechanism for environmental insurance of erosion hazardous lands; institutionalization and implementation of instruments of compensation of losses from erosion in context for stimulation of the implementation of sustainable soil management practices.

\section{References}

1. Adhikari, B. and Nadella, K. (2011), Ecological economics of soil erosion: a review of the current state of knowledge. Annals of the New York Academy of Sciences, vol. 1219, pp. 134-152. https://doi.org/10.1111/j.1749-6632.2010.05910.x.

2. Bakker, M. M., Govers, G., Jones, R. A. and Rounsevell, M. D. A. (2007), The effect of soil erosion on Europe's crop yields. Ecosystems, vol. 10, pp. 1209-1219. https://doi.org/10.1007/s10021-007-9090-3.

3. Panagos, P., Borrelli, P., Poesen, J., Ballabio, C., Lugato, E., Meusburger, K., Montanarella, L. and Alewell, C. (2015), The new assessment of soil loss by water erosion in Europe. Environmental Science \& Policy, vol. 54, pp. 438-447. https://doi.org/10.1016/j.envsci.2015.08.012.

4. Panagos, P., Standardi, G., Borrelli, P., Lugato, E., Montanarella, L. and Bosello, F. (2018), Cost of agricultural productivity loss due to soil erosion in the European Union: from direct cost evaluation approaches to the use of macroeconomic models. Land Degradation \& Development, vol.29, pp.471-484. https://doi.org/10.1002/ldr.2879. 


\section{Agricultural and Resource Economics: International Scientific E-Journal}

http://are-journal.com

5. Panagos, P., Imeson, A., $\quad$ Meusburger, K., Borrelli, P., Poesen, J. and Alewell, C. (2016), Soil conservation in Europe: wish or reality? Land Degradation \& Development, vol. 27, pp. 1547-1551. https://doi.org/10.1002/ldr.2538.

6. Achasov, A. B., Achasova, A. A. and Titenko, A. V. (2019), Determination of soil erosion by assessing hydrothermal conditions of its formation. Global Journal of Environmental Science and Management, vol. 5, spec. is., pp. 12-21. https://doi.org/10.22034/gjesm.2019.SI.02.

7. Bernoux, M., Fileccia, T., Guadagni, M. and Hovhera, V. (2014), Ukraine soil fertility to strengthen climate resilience: preliminary assessment of the potential benefits of conservation agriculture: main report. Washington, DC, World Bank Group, USA.

8. Borrelli, P., Ballabio, C., Panagos, P. and Montanarella, L. (2014), Wind erosion susceptibility of European soils. Geoderma, vol.232-234, pp. 471-478. https://doi.org/10.1016/j.geoderma.2014.06.008.

9. Borrelli, P., Lugato, E., Montanarella, L. and Panagos, P. (2017), A new assessment of soil loss due to wind erosion in European agricultural soils using a quantitative spatially distributed modelling approach. Land Degradation \& Development, vol. 28, pp. 335-344. https://doi.org/10.1002/ldr.2588.

10. Liu, Y., Zhao, L. and Yu, X. (2020), A sedimentological connectivity approach for assessing on-site and off-site soil erosion control services. Ecological Indicators, vol. 115, 106434. https://doi.org/10.1016/j.ecolind.2020.106434.

11. Martín Fernández, L. and Martinez Núñez, M. (2011), Evaluation and control of the risk of soil erosion in Spain: national inventory of soil erosion 20022012. Spanish Journal of Rural Development, vol.1, pp.131-138. https://doi.org/10.1016/j.scitotenv.2011.05.010.

12. Menshov, O., Kruglov, O., Vyzhva, S., Nazarok, P., Pereira, P. and Pastushenko, T. (2018), Magnetic methods in tracing soil erosion, Kharkov region, Ukraine. Studia Geophysica et Geodaetica, vol.62, pp.681-696. https://doi.org/10.1007/s11200-018-0803-1.

13. Pham, T. G., Degener, J. and Kappas, M. (2018), Integrated universal soil loss equation (USLE) and Geographical Information System (GIS) for soil erosion estimation in A Sap basin: Central Vietnam. International Soil and Water Conservation Research, vol. 6, is. 2, pp. 99-110. https://doi.org/10.1016/j.iswcr.2018.01.001.

14. Tessema, Y. M., Jasińska, J., Yadeta, L. T., Świtoniak, M., Puchałka, R. and Gebregeorgis, E. G. (2020), Soil loss estimation for conservation planning in the Welmel Watershed of the Genale Dawa Basin, Ethiopia. Agronomy, vol. 10, no. 6, 777. https://doi.org/10.3390/agronomy 10060777.

15. Shao, Y. (2008), Physics and modelling of wind erosion. Springer, Netherlands. https://doi.org/10.1007/978-1-4020-8895-7.

16. Timchenko, D., Havryliuk, V. and Koliada, V. (2014), Defliatsiini protsesy Volynskoho Polissia Ukrainy: gruntovyi aspekt [Deflationary processes Volyn Polissya of Ukraine: soil aspect], FOP Hrytsak S. Iu., Kharkiv, Ukraine. 
17. Vávra, J., Duží, B., Lapka, M., Cudlínová, E. and Rikoon, J. S. (2019), Socio-economic context of soil erosion: a comparative local stakeholders' case study from traditional agricultural region in the Czech Republic. Land Use Policy, vol. 84, pp. 127-137. https://doi.org/10.1016/j.landusepol.2019.03.005.

18. Bulygin, S. and Antonyuk, D. (2016), Soil erosion in Ukraine. Scientific herald of NULES of Ukraine. Series: Agronomy, vol. 235, pp. 143-151.

19. Kucher, A., Kazakova, I., Kucher, L., Kozak, H., Schraml, A., Koka, H. and Priest, W. (2015), Economics of soil degradation and sustainable use of land in danger of wind erosion. Agricultural and Resource Economics, vol. 1, no. 1, pp. 513. https://doi.org/10.22004/ag.econ.256383.

20. Kucher, A., Kazakova, I., Kucher, L., Schraml, A., Koka, H. and Priest, W. (2015), Sustainable use of land in danger of wind erosion in Ukraine: stakeholder engagement. Agricultural and Resource Economics, vol. 1, no. 2, pp. 5-28. https://doi.org/10.22004/ag.econ.256359.

21. European Soil Data Centre (2021), Wind Erosion. Background information, available at: https://esdac.jrc.ec.europa.eu/themes/wind-erosion.

22. Soil Fertility to Increase Climate Resilience in Ukraine (2014), available at: https://www.worldbank.org/en/news/feature/2014/12/05/ukraine-soil.print.

23. Kucher, A. V. (2017), Economics of agricultural land degradation and soil protection: a case study of Ukraine in Management and safety in food chain, eds A. Walaszczyk, I. Jałmużna, B. Galińska. Lodz University of Technology, Lodz, Poland.

24. Kucher, A. (2019), Economics of soil erosion in Ukraine. Proceedings of the Global Symposium on Soil Erosion, 15-17 May 2019, FAO, Rome, Italy.

25. Yu, S., Wang, L., Zhao, J. and Shi, Z. (2021), Using structural equation modelling to identify regional socio-economic driving forces of soil erosion: a case study of Jiangxi Province, southern China. Journal of Environmental Management, vol. 279, no. 1, 111616. https://doi.org/10.1016/j.jenvman.2020.111616.

\section{Citation:}

Стиль-ДСТУ:

Kucher A., Kucher L., Sysoieva I., Pohrishchuk B. Economics of soil erosion: case study of Ukraine. Agricultural and Resource Economics. 2021. Vol. 7. No. 4. Pp. 27-41. https://doi.org/10.51599/are.2021.07.04.02.

Style-APA:

Kucher, A., Kucher, L., Sysoieva, I. and Pohrishchuk, B. (2021), Economics of soil erosion: case study of Ukraine. Agricultural and Resource Economics, vol. 7, no. 4, pp. 27-41. https://doi.org/10.51599/are.2021.07.04.02. 